\title{
Looking through the African lenses: a critical exploration of the CSR activities of Chinese International Construction Companies (CICCs) in Africa
}

\author{
Oluwasegun Oluwaseyi Seriki@
}

\begin{abstract}
The importance of Chinese International Construction Companies (CICCs) within the construction sector in Africa can no longer be ignored, as these firms hold a considerable amount of market share within the African continent. The construction industry is of high importance to African economic renaissance, and Corporate Social Responsibility (CSR) is becoming a key issue in business processes on the developing continent. Narratives around the implementation of CSR within construction in African economies have been largely one-sided, viewed from foreign perspectives and outsider anecdotes, without engaging locals in evaluating these initiatives. As a result, this paper explores CSR as a critical component of the continued penetration and dominance of Chinese contractors in the highly competitive African construction markets. The paper adopts a quantitative survey to explore the areas of implementation of CSR by CICCs, how they line up against current local and international counterparts and the future of these firms in Africa using CSR as a metric. Residents of Africa's largest economy, Nigeria, who have Chinese-led projects ongoing in their communities, were surveyed for the study, and the findings used to propose solutions for future CSR policy-making in local African communities where Chinese contractors carry out business. The study found that in terms of CSR strategy implementation, CICCs were ranked highly on quality of construction and respect for local laws and customs, but ranked low in perception of employee welfare and environmental protection. The study highlighted that African governments taking responsible leadership by formulating a CSR policy for all international contractors might stem the tide of increasing anti-Chinese rhetoric within the construction sector on the African continent.
\end{abstract}

Keywords: Corporate social responsibility, Chinese International Construction Companies, Strategy, Africa, Nigeria

\section{Introduction}

The importance of the construction industry in every economy cannot be overemphasized, as the sector is considered a key contributor to the creation of employment and contribution to GDP. In Nigeria, which is reputed to be the largest economy on the continent, the sector contributed 3.72\% to GDP in 2017 alone (Ezeana,

\section{Correspondence: seriseg@outlook.com}

Department of Civil and Structural Engineering, College of Engineering and Built Environment, Technological University Dublin, Bolton Street, Dublin, Ireland

Springer Open
2018). Yet the industry is largely ignored in corporate social responsibility studies, despite the high level of foreign investments it enjoys and its contribution to the economy. The Nigerian, and indeed, overall African business landscape is fast becoming a focus on strategy scholars, as it is known as part of the Global South, in addition to Latin American and Asia. Businesses in these regions are gaining global recognition and becoming a central area of focus in recent years (Mihić, Shevchenko, Gligorijević, \& Petrović, 2019). However, there has been an increase in criticisms regarding the non-profit and

(c) The Author(s). 2020 Open Access This article is licensed under a Creative Commons Attribution 4.0 International License, which permits use, sharing, adaptation, distribution and reproduction in any medium or format, as long as you give appropriate credit to the original author(s) and the source, provide a link to the Creative Commons licence, and indicate if changes were made. The images or other third party material in this article are included in the article's Creative Commons licence, unless indicated otherwise in a credit line to the material. If material is not included in the article's Creative Commons licence and your intended use is not permitted by statutory regulation or exceeds the permitted use, you will need to obtain permission directly from the copyright holder. To view a copy of this licence, visit http://creativecommons.org/licenses/by/4.0/. 
civil society centric nature of corporate social responsibility in Africa, with the critique focused at the real business motives and CSR-led potentials for partnership (Hamann \& Acutt, 2003). Some of the issues driving increasing business and foreign direct investments in Africa includes reduced tariffs, quotas, cheap labour, trade-investment agreements and market structures (Broadman, 2007).

\section{Chinese investment in Africa}

China has emerged as one of the leading foreign investors in Africa, based on proceeds from its growing trade surplus, and the recent surge in Chinese investment is increasingly drawing attention from policy-makers and academics, who seek to understand the dynamics behind these investments and the intrinsic benefits of the continent from the China-Africa relationship (Macedo, Pereira, \& Lopes, 2012). China's investment footprint was ranked fourth-largest foreign investor in Africa with an investment of about $\$ 40$ billion as at 2016 (UNCTAD's World Investment 2018 report, cited in Afalli, 2018). Chinese firms have emerged as one of the strongest contenders in the African market, coming behind just the US, UK and France (ibid.). The growing presence of Chinese International Construction Companies (CICCs) within the business landscape in Africa, is not without the support of Chinese financial institutions, aiming at increasing the export of Chinese products and service (Co, 2014). However, as the dominance of Chinese contractors expands within the African construction markets, questions have arisen as to the sustainable nature of these projects and how these firms perform in terms of corporate social responsibility (CSR). Although, few studies exist which explore CSR initiatives of Chinese contractors in Africa, these studies are sometimes treated with suspicion as they are usually funded by China-affiliated firms and not independent researchers. A need has therefore arisen for a different perspective, from the client's side into the subject of CSR of CICCs in Africa, particularly from an independent research perspective. This independent perspective is paramount because several fears still exist in the mind of people living on the African continent, based on the previous experience with Western nations, coupled with the fear of exploitation and neo-colonialism (Anthony, 2013). These issues amongst others provide the premise on which this research was conducted.

\section{CSR and construction in Africa}

The implementation of CSR has now been accepted as a major metric for evaluating sustainable business practices in the construction sector (Seriki, 2020a). There is not much evidence within the literature of how Chinese contractors, who hold the largest market share in the African construction market have implemented CSR in
African construction markets, neither are there robust studies that evaluate same using data gathered from the African continent. Part of the reasons for paucity of studies in this area is the lack of CSR communication on the part of these Chinese firms and the nature of suspicion of corporate communication, where people believe that organizations overstate their social behavior (Tata \& Prasad, 2015). Another issue is the lack of trust between Africans and the Chinese, where many believe that their leaders have made unfavourable deals with China, leading to increasing consternation and suspicion in the attitude of African countries to Chinese investors (Ngome, 2007).

This study aims to fill that gap in knowledge by providing a different perspective to the conversation on CSR in construction, using insights gleaned from residents in local African communities. This research inquiry reports on three areas of CSR within Chinese construction firms in Africa, namely: CSR performance in critical areas; a comparative analysis between CICCs CSR strategy and local/international construction firms; and a futuristic analysis of whether or not Africans will recommend a Chinese contractor for work based on current CSR performance.

One of the key issues already established within the CSR process of Chinese companies in Africa is the poor record of workers' welfare and labour abuse (Corkin, 2012). Chinese firms in Angola have been criticised for being reluctant to hire local labour, preferring to bring labour from China. Other accusations have included transparency/corruption issues (Co, 2014), environmental governance (Peh \& Eyal, 2010), respect for local laws and customs amongst others. These issues determine the future potential and competitiveness of CICCs in the continent's largest economy and the African continent as a whole.

\section{Case description: approach taken /method of analysis \\ Theoretical background}

The key theoretical underpinning of this study lies within the intersection of organisational change management and stakeholder theory (Maon, Swaen, \& Lindgreen, 2007). The central aim of adopting this theoretical lens to CSR strategy implementation is to align the dynamic demands of the business and social environment with the identified and well-managed expectations of stakeholders (Dawson, 2003). The emphasis of stakeholder theory is organisational survival and success, driven by the firm's ability to generate sufficient profit, value, or satisfaction for its primary stakeholders, with this value not targeted exclusively for shareholders but all the stakeholders (Clarkson, 1995). The justification for this underlying theoretical base is that CICCs in Africa face the challenge of identifying 
stakeholders involved in the CSR implementation process, and also using CSR as an organisational change management tool.

The research question can thus be articulated as follows: "What is the nature/perception of CSR strategy implementation by Chinese International Construction Companies in Africa from a local citizen's perspective?". The paper will predominantly employ the perspective of Africans as key stakeholders within the CSR implementation process in Africa, with the intent of proposing solutions for effecting change within the process within CICCs.

\section{Research method}

Bell (2005) espoused that there is no standard methodology that applies to all research problems, and argued that methodology ought to be selected based on the nature and scope of the topic at hand and the type of data available. The objective of the paper is to "..determine perceptions of the local African residents about CICC CSR strategy implementation", the research purpose is deemed explanatory (Saunders, Lewis, \& Thornhill, 2009). Robson (2002) argued that exploratory research helps researchers devise a means to discover happenings in research and gain new insights without investigating reasons. Therefore, this research work is exploratory in nature, and does not propose any hypothesis, since the study does not seek to investigate causality, but only to link observed data to pre-identified themes (Seriki, 2020b).

The methodological approach most suited to this study is the inductive approach, which allows for the construction of generalisations based on patterns observed in the study (Gjølberg, 2011). Under this type of approach, the analysis on the data is performed on a 'bottom-up' basis, linking the raw data to identified themes within the literature (Bowen, Allen, Edwards, Cattell, \& Simbayi, 2014). In terms of philosophical stances, several CSR and organisational change studies tend to follow the positivist and constructivist approaches (e.g. Bonuedi, 2016; Gjølberg, 2011; Wicks \& Freeman, 1998), however, this study adopted the pragmatic position, as the objective was mainly to interpret reality from the African perspective. This position was taken due to the dual nature of the study (Africans/ Chinese companies), acknowledging Saunders et al. (2009) argument that pragmatism considers that no single viewpoint can ever give the entire picture. This paper only gives one viewpoint i.e. that of African residents, using Nigerians as a case study, and yet acknowledges that there are other multiple viewpoints of reality especially in relation to CSR activities of CICCs in Africa.

The study adopted the single (mono)- methodological choice, which could be either qualitative or quantitative
(Subedi, 2016). Teddlie and Tashakkori (2009) outlined that once the nature of the research questions have been established, the researcher can decide whether they can be answered by either quantitative (QUANT) or qualitative (QUAL) data. For the purpose of this study, which is mainly exploratory, the researcher deemed that all of the research questions and objectives can be reached using QUANT data, and thus deemed the mono method design more appropriate. In addition, the survey research strategy was considered sufficient for the study as it allows quality data to be obtained from a relatively large sample of people within a pre-determined population (Kelley, Clark, Brown, \& Sitzia, 2003).

In every research project, it is crucial to record the timeline over which the data was collected, which is known as the time horizon (Trochim, 2006). These can either be cross-sectional (single point in time) or longitudinal (taking place over time). This study was crosssectional, as the data was collected over a defined period of time i.e. 1 month. The sampling technique adopted in the study is random sampling, which is a type of probabilistic sampling where respondents are randomly selected in a scattered format from the sample population (Bryman, 2012). The link to the online survey was posted online via Survey Monkey and exported to Excel for analysis, and random Nigerian respondents were able to fill in the survey from a reliable and comprehensive register of the research population (Warner, 1965).

A total of 114 respondents filled in the survey over the 30-day period, and demographic data survey respondents is presented in Table 1 below.

\section{Analysis and findings}

This section of the study sought to investigate the overall perception of the African respondents about the CSR interventions of CICCs within their local communities, with a realistic evaluation of CSR implementation and its focus areas. CICCs were appraised based on six (6) key areas identified as critical during the review of the literature. The first set of findings relate to how Chinese firms are perceived to have improved in terms of quality of services offered as opposed to previous notions that portrayed Chinese construction in terms of low-quality construction. Quality in construction is considered one of the most critical elements in CSR evaluation for contractors as it highlights that a contractor can respond effectively to the many demands placed on them (Griffith, 2011). Hence, the ranking of CICCs is surprising as earlier authors within CSR studies on Chinese firms have criticised them for not paying attention to quality as much as they could have (Jiang \& Wong, 2016).

More details of the overall rating of CSR activities of CICCs are displayed in Fig. 1 below. 
Table 1 Profile of respondents

\begin{tabular}{|c|c|c|c|}
\hline & Frequency & $\%$ responses & Cumulative $\%$ \\
\hline \multicolumn{4}{|l|}{ Respondent profile } \\
\hline Male & 81 & 71.1 & 71.1 \\
\hline Female & 33 & 28.9 & 100.0 \\
\hline \multicolumn{4}{|l|}{ Age } \\
\hline$<21$ years & 7 & 6.2 & 6.2 \\
\hline $21-60$ years & 106 & 92.9 & 99.1 \\
\hline$>60$ years & 1 & 0.9 & 100.0 \\
\hline \multicolumn{4}{|l|}{ Educational level } \\
\hline No formal education & 1 & 0.9 & 0.9 \\
\hline At least primary school & 11 & 9.6 & 10.5 \\
\hline High school degree & 6 & 5.3 & 15.8 \\
\hline University degree & 50 & 43.8 & 59.6 \\
\hline Postgraduate degree & 45 & 39.5 & 99.1 \\
\hline Other & 1 & 0.9 & 100.0 \\
\hline \multicolumn{4}{|l|}{ Ownership structure } \\
\hline City or urban community & 103 & 90.4 & 90.4 \\
\hline Suburban community & 8 & 7.02 & 97.42 \\
\hline Rural community & 2 & 1.75 & 99.1 \\
\hline Other & 1 & 0.9 & 100.0 \\
\hline
\end{tabular}

\section{What is your overall rating of CICCs regarding CSR?}

Protection of landmarks/cultural heritage

Respect for local laws, customs and traditions

Transparency
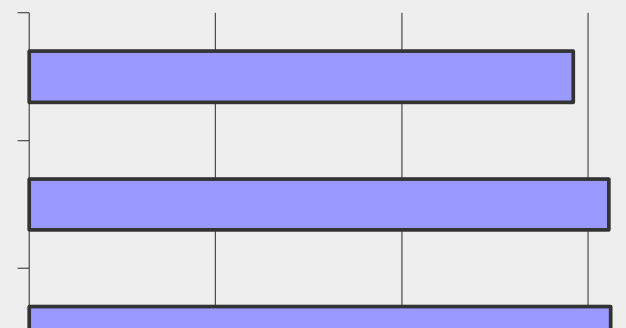

Quality of construction

Environmental protection

Workers welfare (Work hours of staff, Wages,

Work ethics)

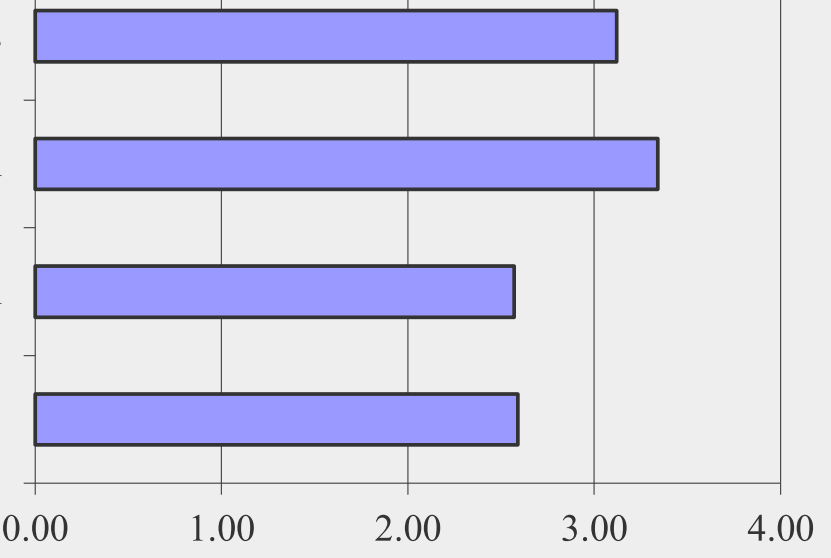

Fig. 1 Overall rating of CSR activities of CICCs by African respondents 
Implementation: rating of CICCs in terms of CSR

The reason for a shift in perception of Africans about Chinese construction quality cannot be conclusively determined at this point, due to several reasons. First, due to varying quality standards and perceptions, the pointers used in rating quality construction may differ (Ulutaş Duman, Giritli, \& McDermott, 2016). Secondly, due to the small sample size, this recorded change in perception may not be fully explained unless via further analysis (i.e. interviews). It is important to note that having an above-average rating in quality of construction is something new for Chinese contractors in Africa, as there is still a popular misperception that Chinese-built infrastructure is of poor quality (Olander \& van Staden, 2018).

The second-highest ranked factor in Fig. 1 is the perception that CICCs have respect for local laws and customs. Chinese contractors have long been reputed for non-interference in local, socio-political beliefs and customs; they rather carry along their business without interfering in social, political or religious matters. Chen et al. (2009) already studied Chinese firms and found that they attached great importance to meeting local laws and regulations, giving utmost respect to local religious beliefs and customs. CICCs are known to not only be politically neutral, but also keen on business only interests, without meddling with matters of customary importance. This is in line with China's non-intervention policy in Africa (Mumuni, 2017), which is lauded by some and criticised by others. CICCs therefore hold a strong reputation for not considering local laws and custom as a problem, but do their best to conform to it with minimal interference.

The third ranked factor in the study is that respondents see CICCs as placing emphasis on the protection of landmarks and cultural heritage structures in their construction activities. Landmarks and cultural heritages such as statues, monuments, shrines, and religious centres are of high importance to African locals, and it is the responsibility of the contractor to fashion their design in such a way that it accommodates these structures in its construction phase. Demolition of such heritage structures are usually met with stiff resistance and extreme measures, hence most contractors would rather re-design their structure in a way that it accommodates the re-positioning of the heritage structure or leaves it largely untouched. Tang and Li (2009) outlined that as Chinese multinational corporations expand into every corner of the world, they have to adapt their business practices to align to local cultures, which includes respect for the local needs and cultural heritage.

Fourth, looking at the level of transparency of CICCs, the rating is something worthy of note again in this study. Chinese firms have been synonymous with bribery and corruption in times past, but it is evident that their rating in terms of transparency has clearly improved within the African community. This may be due to stricter anti-corruption rules being enforced by the current administration in Beijing, which has clamped down seriously on corruption in recent times. Alves (2013) had earlier decried the lack of transparency embedded within Chinese infrastructural loans in Africa and the effect of same on Africa's overall governance. CICCs need to improve on transparency within the bidding and execution process within the African construction sector.

CICCs still rank low in environmental protection and workers welfare as seen in Fig. 1, pointing to the need to improve in their drive for environmental sustainability and welfare of local labour and improving working conditions, which has led to recent protests even within Nigeria (Brautigam, 2013) and has generated huge concerns from environmental and labour activists. Liao, Xue, Liu, and Fang (2015) highlighted labour practices as a critical metric for Chinese contractors operating in international markets, and they included the improvement of staff welfare as one of the key CSR evaluation criteria. They cited measures such as purchasing health insurance for employees, elimination of employee discrimination, harassment, maltreatment, and physical punishment as key steps in the right direction for Chinese International contractors.

The findings above have shown that in terms of the implementation of CSR, CICCs are perceived to be doing better in terms of quality of construction and respect for local laws and customs, however much remains to be done in terms of employee welfare and environmental protection. Ma (2011) lamented the lack of employee participation in CSR programs, and these thoughts are echoed by Roza (2016), who stressed that employee should be engaged as part of the stakeholders in CSR implementation. Involving employees themselves in the CSR process would see to it that employee welfare is prioritised within CICCs. Environmental protection which ranks lowest is no surprise, as Mol (2011) already highlighted several criticism to Chinese firms operating in Africa with respect to their prioritisation of environmental protection. There is, therefore, a clear need for African policymakers to decide whether to pursue a policy-driven approach to encouraging more responsibility on the part of CICCs to the environment and employee welfare. It is yet to be determined whether a policy should be enacted in this regard or it is best left to be driven by the contractors themselves.

\section{CSR activities of Chinese firms in comparison with local and foreign counterparts}

In this section, a comparative analysis of the CSR activities of CICCs in comparison to their local and 
international counterparts in the same industry is conducted. Othman and Mia (2008) highlighted previously that Western firms long held dominance within infrastructure investments in Africa, but have now been challenged by China's State Owned Enterprises (SOEs). It is therefore critical to benchmark how Africans perceive CSR implementation by the international counterparts (i.e. firms from Europe and North America), and locally owned firms in Nigeria.

The findings show that the CSR activities of CICCs are quite superior to that carried out by local contractors, and that of international firms (see Table 2). The stark contrast in perception of comparability between CSR strategies of local firms, CICCs and other international firms shown in Table 2 may be due to the disparity in perception of what pertains to CSR, as the concept of CSR by each region may differ. For instance, CICCs have been known to place more emphasis on cost-effectiveness and on-time delivery while minimising environmental damage, however for local contractors, sustainability is not considered important to their CSR activities. Also, local contractors may not be under compulsion to implement CSR as biased against international firms such as CICCs and Western construction firms.

Gjolberg (2009) who has studied CSR practices extensively in about 20 countries in different regions concluded that comparison in CSR between countries is limited to the country of origin of the company under analysis. This underscores the fact that CSR comparison, especially in developing countries is dependent on the context under consideration. While context is a vast field within CSR studies and may play a role in this comparison, the only context applied here is the geographical context i.e. Nigerian contractors (local competitors) and foreign contractors (non-Chinese international contractors). Aside from these, other contextual factors were not taken into consideration during the gathering of data for this study.

Quite a number of respondents (38.05\%) believe that Chinese CSR methods are similar to that of either foreign counterparts, suggesting lack of innovation or creativity on the part of CICCs when it comes to CSR. This is further supported by $22.83 \%$ of respondents who see the CSR initiatives of Chinese firms as the same with those embarked on by other foreign firms. Does this mean that Chinese firms need to need to design innovative methods of CSR implementation to distinguish themselves from the pack?

Despite the underlying issues of cultural differences between local and foreign construction firms, the lack of a distinguishing CSR policy recognizable by locals may be an issue of concern for CICCs. Unlike in more developed economies, where there are strong institutional

Table 2 Comparison of CICCs, local and international firms regarding CSR

How well can you compare the CSR strategies of Chinese companies to those of their local/international

construction industry counterparts? $($ comparable $=$ similar; incomparable $=$ superior $)$

\begin{tabular}{lllllll}
\hline Answer & & Somewhat & & Somewhat & & Cumulative \\
Options & Comparable & Same & Incomparable & Response \\
& & comparable & & incomparable & & $(\%)$
\end{tabular}

Local

construction $\quad 10.87 \% \quad 25 \%$

$14.13 \% \quad 40.2 \% \quad 9.78 \%$

companies

International

Construction $\quad 11.96 \% \quad 26.09 \%$

$22.83 \% \quad 21.74 \%$

companies 
environments that monitor and evaluate CSR activities of firms, African countries may have their own range of factors for measuring the level and effectiveness of CSR measures by performing firms. Should the same CSR benchmarks exist for local and foreign contractors alike? These issues are hardly discussed in CSR literature in Africa with the seriousness it deserves and needs to be considered for future investigation.

Zadek et al. (2009) delved somewhat into the issues faced by CICCs, especially since they mostly only understand foreign language (Mandarin), use foreign equipment and eat foreign food. There appears to be no cross-fertilisation of knowledge and cultural exchanges between the Chinese contractors and local contractors, so their CSR activities might be considered worse off than that of local firms.

Given that there exists no current best practices model or benchmark for CSR in the construction sector in Africa, the evidence from the study supports while CICCs might be doing well in comparison to other international contractors, they are faring much less in CSR terms when compared to local firms. This is an interesting finding for CICCs, and they would benefit from liaising with local contractors to learn how they can implement and scale CSR initiatives, in view of the long-term sustainability of doing business on the African continent.

\section{The future prospects of CICCs in African markets based} on CSR

Peters (2009) outlined that CSR was a critical strategic tool for predicting the future pathways during times of crisis, and with the growing anti-China sentiments on the African continent, CSR is a critical measurement tool for predicting long-term sustainability of Chinese construction business in Africa. There is a need to measure the optimism of locals around the prospects of CICCs within the African continent, to gauge the level of trust of the respondents about the increasing Chinese presence within African construction. The results in this section are shown in Fig. 2.

An interesting result is presented in Fig. 2, with most of the respondents responding in the affirmative (i.e. will recommend a Chinese contractor for work in their community based on their CSR performance). With about a fifth of being indifferent about CICCs continued work in Africa, and another combined fifth $(15.3 \%+6.1 \%)$ expressing negative sentiments on the probability of recommending Chinese firms for work in construction, CICCs should consider this an area of concern for their business in Africa. Overall, the results portray respondents leaning between indifference and positivity about the future of CICC continuity in business in Africa.

\section{To what extent would you recommend a Chinese Construction company for a project in Nigeria and Africa at large based on their CSR activities?}

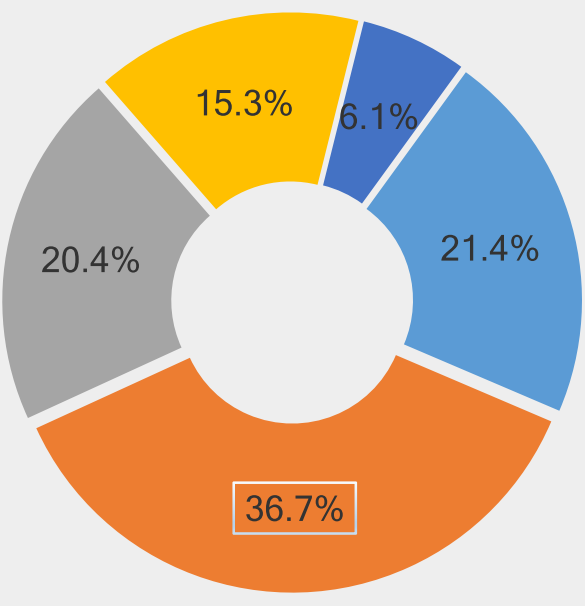

- I will highly recommend a Chinese contractor

- I may recommend a Chinese contractor

Indifferent

- I may not recommend a Chinese Contractor

a I will never recommend a Chinese company

Fig. 2 Futuristic outlook of Africans regarding CICCS based on CSR 


\section{Conclusions}

\section{Theoretical implications}

Having explored three key areas in the CSR implementation of CICCs, particularly in the Nigerian construction market, the following theoretical/ practical implications are realised:

\section{Implications for CSR strategy within African construction}

African respondents rate CICCs high on quality of construction and respect for laws and customs, but they rate them low on workers' welfare i.e. work hours, wages and work ethics. To ensure sustained competitiveness within the African market, CICCs need to move beyond standard norms of CSR and engage the community, asking them "what do you perceive as CSR?" and how these initiatives can be best tailored to their needs.

\section{Contribution to strategy literature}

One of the key business strategies is differentiation (Porter, 1980), and this paper has shown the need for CICCs to differentiate themselves from the local/foreign contractors by creating a unique value-added factor to their CSR initiatives. If these firms are serious about increasing market share, they cannot keep doing what local/foreign firms are doing; they need to set themselves apart from the pack.

\section{Practical implications for CICCs}

While there is optimism that Africans would be convenient with recommending Chinese continued presence within work in construction, the indifference and negative sentiments expressed by some may be something worth looking at in future studies. Although it is understood that there cannot be a consensus on the CSR implementation of CICCs based on diversity in perceptions, the almost one-fifth portion of respondents who hold a largely negative view of future activities of these firms on the African continent are worth investigating as they might pose a threat to future business of CICCs.

\section{Limitations}

As with every research work, a number of limitations were encountered in the course of the study. Three pertinent ones are now highlighted. First, there is no central or widely used metric for CSR performance measurement within construction, hence posing a limitation to the study. The author developed alternative theoretical metrics such as quality, transparency, and workers' welfare among others in order to overcome this limitation. Another limitation faced was the large sample population, yet relatively small sample size, which was due to the survey being administered online. It was impossible to get a sizable population to respond to the survey, especially in areas where CICCs operate, due to problems such as access to internet and educational level of the respondents. Lastly, the quantitative nature of the study meant that limited insights could be gleaned from the responses. Qualitative methods have been shown to deliver more in-depth, detailed outcomes within CSR studies (Ásványi, 2009), and is recommended for future research.

\section{Recommendations/outlook}

It is recommended that a longitudinal study, preferably interviews be conducted with locals in communities where CICCs undertake work in Africa. This is in order to capture the thoughts and sentiments of locals regarding the increasing dominance of the firms in Africa, and understand how the CSR initiatives implemented - if any- affect the lives of the recipients. It is also critically important for African governments to show critical leadership via the formulation of a construction-industry focused CSR policy, not only for Chinese international contractors but also for all local/international contractors who do business on the continent.

\section{Abbreviations \\ CSR: Corporate social responsibility; CICCs: Chinese International Construction Companies \\ Acknowledgements \\ The author acknowledges the assistance of Dr. Li Xiaodong of Tsinghua University, Beijing, China, who supervised the research project.}

Author's contributions

OS contributed the entire contents of the manuscript, including the data collection, analysis and interpretation. OS also was solely responsible for the writing of the manuscript, being the primary reader and approver of the final manuscript

\section{Authors' information}

Oluwasegun Seriki is a Sino-African relationships expert, with experience of construction and infrastructure collaborations between China and Africa. He is currently the Industry Research Manager at the School of Civil and Structural Engineering, TU Dublin, Ireland.

\section{Funding}

The study was conducted as part of a research project, which was partly funded by the China Scholarship Council (CSC), Tsinghua University Scholarship and Faith Medical Centre, North Carolina, USA.

Availability of data and materials

The datasets generated and/or analyzed during the current study are not publicly available due to ongoing publications from the dataset but are available from the corresponding author on reasonable request.

\section{Competing interests}

The author declares that they have no competing interests.

Received: 3 September 2020 Accepted: 27 November 2020

Published online: 11 December 2020

\section{References}

Afalli, A. (2018). How to separate myths and realities of China's role in tackling Africa's infrastructure deficit. Retrieved from https://qz.com/1334749/how-toseparate-the-myths-and-realities-of-chinas-role-in-tackling-africasinfrastructure-deficit/.

Alves, A. C. (2013). China's "win-win" cooperation: Unpacking the impact of infrastructure for-resources deals in Africa. South African Journal of International Affairs, 20(2), 207-226. 
Anthony, R. (2013). Infrastructure and influence: China's presence on the coast of East Africa. Journal of the Indian Ocean Region, 9(2), 134-149. https://doi.org/ 10.1080/19480881.2013.847553.

Ásványi, K. (2009). CSR communication of a large bank. In Proceedings of FIKUSZ'09 Symposium for Young Researchers (pp. 17-28).

Bell, J. (2005). Doing your research project. Buckingham: Open University Press.

Bonuedi, A. A. (2016). An exploration of corporate social responsibility executives perspectives of corporate social responsibility reporting and stakeholder management in Ghana, (10278084)

Bowen, P., Allen, Y., Edwards, P., Cattell, K., \& Simbayi, L. (2014). Guidelines for effective workplace HIV/AIDS intervention management by construction firms. Construction Management and Economics, 32(4), 362-381.

Brautigam, D. (2013). China in Africa: The real story: Nigerian workers protest conditions at Chinese construction projects. Chinaafricarealstory.com Available at: http://www.chinaafricarealstory.com/2013/02/nigerian-workers-protestconditions-at.html.

Broadman, H. (2007). Africa's silk road: China and India's new economic frontier. Washington: The World Bank.

Bryman, A. (2012). Social research methods, (4th ed.). Oxford: Oxford University Press.

Clarkson, M. B. E. (1995). A stakeholder framework for analyzing and evaluating corporate social perfromance. Academy of Mangement Review, 20(1), 92-117.

Co, C. Y. (2014). Chinese contractors in developing countries. Review of World Economics, 150, 149-171.

Corkin, L. (2012). Chinese construction companies in Angola: A local linkages perspective. Resources Policy, 37, 475-483.

Dawson, P. M. (2003). Organizational change stories and management research: Facts or fiction.

Ezeana, F. (2018). Here are major factors that helped Nigeria's economy climb out of recession in 2017 - The Nerve Africa. Retrieved from https://thenerveafrica. com/14957/nigeria-gdp-economic-growth-2017/

Gjolberg, M. (2009). Measuring the immeasurable? Constructing an index of CSR practices and CSR performance in 20 countries. Scandinavian Journal of Management, 25(1), 10-22

Gjølberg, M. (2011). Explaining regulatory preferences: CSR, soft law, or hard law? Insights from a survey of Nordic pioneers in CSR. Business and Politics, 13(2), 1-31.

Griffith, A. (2011). Fulfilling contractors' corporate social responsibilities using standards-based management systems. International Journal of Construction Management, 11(2), 37-47.

Hamann, R. \& N. Acutt (2003). How should civil society (and the government) respond to 'corporate social responsibility'? A critique of business motivations and the potential for partnerships. Development.

Jiang, W., \& Wong, J. K. W. (2016). Key activity areas of corporate social responsibility (CSR) in the construction industry: A study of China. Journal of Cleaner Production, 113, 850-860.

Kelley, K., Clark, B., Brown, V., \& Sitzia, J. (2003). Good practice in the conduct and reporting of survey research. International Journal for Quality in Health Care, 15(3), 261-266.

Liao, P. C., Xue, J., Liu, B., \& Fang, D. (2015). Selection of the approach for producing a weighting scheme for the CSR evaluation framework. KSCE Journal of Civil Engineering, 19(6), 1549-1559.

$\mathrm{Ma}, \mathrm{H}$. (2011). The effects of corporate social responsibility on employee engagement. ProQuest Dissertations and Theses, 98(April). https://doi.org/10, 1007/s40812-016-0029-6.

Macedo, J. B. D., Pereira, L. B., Lopes, J. M. (2009). Drivers of China's Foreign Direct Investment into Africa (No. wp544). Universidade Nova de Lisboa, Faculdade de Economia.

Maon, F., Swaen, V., \& Lindgreen, A. (2007). Mainstreaming the corporate social responsibility agenda: A change model grounded in theory and practice, (vol. 32, pp. 1-62).

Mihić, M. M., Shevchenko, S., Gligorijević, E. D., \& Petrović, D. (2019). Towards strategic corporate social responsibility approach in international projectsreview of south-south cooperation: A case study of Chinese projects in Angola. Sustainability (Switzerland), 11(10). https://doi.org/10.3390/ su11102784.

Mol, A. P. J. (2011). China's ascent and Africa's environment. Global Environmental Change, 21(3), 785-794. https://doi.org/10.1016/j.gloenvcha.2011.03.015.

Mumuni, S. M. (2017). China's non-intervention policy in Africa: Principle versus pragmatism. African Journal of Political Science and International Relations, 11(9), 258-273.
Ngome, I. (2007). Cameroonian perceptions of the Chinese invasion. Retrieved 11/21/2020 http://www.africafiles.org/article.asp?ID=15986.

Olander, E., \& van Staden, C. (2018). Chinese-built infrastructure in Africa may not be as bad as some think. Retrieved from https://www.huffingtonpost.com/ entry/china-infrastructure-africa_us_57b32e3ae4b0863b0284d2b3.

Othman, A. E. E., \& Mia, B. (2008). Corporate social responsibility for solving the housing problem for the poor in South Africa. Journal of Engineering, Design and Technology, 6(3), 237-257.

Peh, K. S. H., \& Eyal, J. (2010). Unveiling China's impact on African environment. Energy Policy, 38, 4729-4730.

Peters, A. (2009). Pathways out of the crisis: CSR as a strategic tool for the future pathways out of the crisis.

Porter, M. E. (1980). Competitive Strategy, New York Free Press.

Robson, C. (2002). Real-world research: A resource for social scientists and practitioner-researchers (Vol. 2). Oxford: Blackwell.

Roza, L. (2016). Utilizing corporate social responsibility to establish multi-dimensional person-environment fit. Employee engagement in corporate social responsibility; A collection of essays.

Saunders, M., Lewis, P., \& Thornhill, A. (2009). Research methods for business students. Pearson education.

Seriki, O. (2020a). Knowledge transfer in the African construction sector: The CSR and sustainable development nexus. In The future of the UN sustainable development goals, (pp. 45-67). Cham: Springer.

Seriki, O. O. (2020b). A framework for strategic decision-making in construction professional service firms (Doctoral dissertation, Technological University Dublin, Dublin, Ireland). Retrieved from http://arrow.tudublin.ie.

Subedi, D. (2016). Explanatory sequential mixed method design as the third research community of knowledge claim. American Journal of Educational Research, 4(7), 570-577.

Tang, L., \& Li, H. (2009). Corporate social responsibility communication of Chinese and global corporations in China. Public Relations Review, 35(3), 199-212.

Tata, J., \& Prasad, S. (2015). CSR communication: An impression management perspective. Journal of Business Ethics, 132(4), 765-778.

Teddlie, \& Tashakkori (2009). Foundations of mixed methods research: Integrating qualitative and quantitative approaches in social and behavioral sciences. California: Sage Publication.

Trochim, W. M. K. (2006). The research methods knowledge base, (2nd ed., ). Cincinnati: Atomic Dog Publishing.

Ulutaş Duman, D., Giritli, H., \& McDermott, P. (2016). Corporate social responsibility in construction industry. Built Environment Project and Asset Management, 6(2), 218-231.

Warner, S. L. (1965). Randomized response: A survey technique for eliminating evasive answer bias. Journal of the American Statistical Association, 60(309), 63-69.

Wicks, A. C., \& Freeman, R. E. (1998). Organization studies and the new pragmatism: Positivism, anti-positivism, and the search for ethics. Organization Science, 9(2), 123-140.

Zadek, S, Chen, X, Zhaoxi, L, Tao, J, Yan, Z, Yu, K, Forstater, M, Morgan, G (2009) Responsible Business in Africa Chinese Business Leaders' Perspectives on Performance and Enhancement Opportunities, Working Paper 54, Corporate Social Responsibility Initiative, Harvard Kennedy School, Cambridge, Mass.

\section{Publisher's Note}

Springer Nature remains neutral with regard to jurisdictional claims in published maps and institutional affiliations. 